\title{
Heterocyst envelope thickness, heterocyst frequency and nitrogenase activity in Anabaena flos-aquae: influence of exogenous oxygen tension
}

\author{
N. Kangatharalingam, ${ }^{1}$ John C. Priscu ${ }^{1 *}$ and Hans W. PaerL ${ }^{2}$ \\ ${ }^{1}$ Department of Biology, Montana State University, Bozeman MT 59717, USA \\ ${ }^{2}$ Institute of Marine Sciences, University of North Carolina-Chapel Hill, Morehead City, NC 28557, USA
}

(Received 24 February 1992; revised 15 July 1992; accepted 27 July 1992)

\begin{abstract}
The heterocyst envelope of the $\mathrm{N}_{2}$-fixing cyanobacterium Anabaena flos-aquae thickened as exogenous $\mathrm{O}_{2}$ partial pressure $\left(\mathrm{pO}_{2}\right)$ was increased from 5 to $40 \mathrm{kPa}$. The majority of the thickening occurred in the glycolipid layer area of the envelope. Such thickening appears to be an $\mathrm{O}_{2}$-induced mechanism for providing a greater $\mathrm{O}_{2}$ diffusion barrier against $\mathrm{O}_{2}$ inhibition of nitrogenase. Nitrogenase activity decreased at $\mathrm{pO}_{2}$ levels above ambient $(20 \mathrm{kPa})$, indicating that a thicker envelope is not completely effective as a barrier to $\mathrm{O}_{2}$ diffusion. However, when cultures grown at $10 \mathrm{kPa}$ and $40 \mathrm{kPa} \mathrm{pO}_{2}$ were transferred to ambient $\mathrm{pO}_{2}$, the $40 \mathrm{kPa} \mathrm{pO}_{2}$ cells showed higher nitrogenase activity $24 \mathrm{~h}$ after transfer compared to those grown at $10 \mathrm{kPa}$ or ambient $\mathrm{pO}_{2}$, indicating $\mathrm{O}_{2}$-protection of nitrogenase by thicker heterocyst envelopes. Heterocyst frequency was lowest at $20 \mathrm{kPa} \mathrm{O}_{2}$.
\end{abstract}

\section{Introduction}

In oxygenic phototrophic cyanobacteria, exogenous oxygen tension is the net product of consumption through respiration, release through oxygenic photosynthesis and physical processes such as diffusion. The nitrogenase enzyme complex responsible for the conversion of molecular nitrogen to ammonium in diazotrophs is inactivated by oxygen (Fay \& Cox, 1967; Robson \& Postgate, 1980). Various physiological, morphological and ecological strategies exist among different diazotrophs to overcome this dilemma (e.g. Carlton \& Paerl, 1989; Carpenter \& Price, 1976; Kangatharalingam et al., 1991). An important structural feature providing protection against oxygen inactivation of nitrogenase in certain cyanobacteria is the multi-component envelope of the heterocyst (Wolk, 1982). Despite the presence of heterocysts, filamentous cyanobacteria such as Anabaena and Aphanizomenon exhibit some degree of nitrogenase inhibition when exogenous oxygen levels are elevated above ambient. This indicates that the oxygen diffusion barrier afforded by the heterocyst envelope is not completely effective against increases in external oxygen tension (Murry et al., 1984; Murry \& Wolk, 1989).

Structures analogous to heterocysts, called vesicles in

\footnotetext{
- Author for correspondence.
}

Abbreviations: Chl $a$, chlorophyll $a$; TEM, transmission electron microscopy. the actinorhizal diazotroph Frankia, have thin walls in cultures grown at low partial pressure of $\mathrm{O}_{2}\left(\mathrm{pO}_{2}\right)$ while having thicker walls at high $\mathrm{pO}_{2}$ (Parsons et al., 1987). This phenomenon has not been reported among cyanobacterial heterocysts, except for the observation that in Anabaena spp. the heterocyst envelope is poorly developed under low- $\mathrm{pO}_{2}$ and anaerobic conditions (Kulasooriya et al., 1972; Rippka \& Stanier, 1978). Only short-term effects of $\mathrm{pO}_{2}$ or $\mathrm{O}_{2}$-supersaturation on nitrogenase activity in cyanobacteria have been reported (Murry et al., 1984; Paerl, 1978).

Physiological (environmental) factors such as light intensity, combined nitrogen availability and assimilable organic carbon sources affect the frequency of heterocyst formation (Fogg, 1949). Heterocyst frequency of Anabaena cylindrica under highly elevated $\mathrm{CO}_{2}$ levels with no $\mathrm{O}_{2}$ was shown to be higher than that in air (Kulasooriya et al., 1972). However, we are unaware of reports on the effect of varied $\mathrm{pO}_{2}$ alone on heterocyst frequency. Because heterocysts are the primary sites of nitrogenase synthesis (Elhai \& Wolk, 1990), their frequency is often positively related to corresponding nitrogenase activity (Smith et al., 1987).

We have examined the influence of external $\mathrm{pO}_{2}$ on heterocyst envelope thickness, heterocyst frequency and nitrogenase activity in Anabaena flos-aquae. This study provides information on the inter-relationships of these factors and the physiological implications of exogenous $\mathrm{pO}_{2}$. 


\section{Methods}

Cultures and general experimental conditions. Anabaena flos-aquae, isolated from Hebgen Lake, Montana, was grown and maintained in batch cultures at $25 \pm 1{ }^{\circ} \mathrm{C}$ in ASM medium (Allen, 1968) without an inorganic nitrogen source (ASM-). An irradiance of $200 \mu \mathrm{mol} \mathrm{m}^{-2} \mathrm{~s}^{-1}$ was supplied by 'cool white' fluorescent lamps under a $12 \mathrm{~h}$ light/dark cycle.

Nine replicate sealed serum bottles (unit capacity $117.5 \mathrm{ml}$ ) were used per $\mathrm{pO}_{2}$ treatment, each containing $20 \mathrm{ml} \mathrm{ASM}{ }^{-}$medium and $0.5 \mathrm{ml} 5$-d-old $A$. flos-aquae inoculum in exponential growth. Temperature and irradiance were the same as for culture maintenance. The bottles were incubated with agitation at 60 r.p.m. on a gyrotary shaker. Gas mixtures were replenished every $5 \mathrm{~d}$ during the $12 \mathrm{~d}$ course of the experiment (see below).

Chlorophyll assay. Chlorophyll $a$ (Chl $a$ ), used to normalize nitrogenase activity, was determined on samples vacuum-filtered onto Whatman GF/C filters. Warm $\left(70^{\circ} \mathrm{C}\right) 95 \%(\mathrm{v} / \mathrm{v})$ ethanol was added to the sample filter, which was then vortexed for $2 \mathrm{~min}$ and allowed to cool to room temperature for $>12 \mathrm{~h}$ (Sartory \& Grobbelaar, 1984). Either a spectrophotometer (Varian DMS 80) or a fluorimeter (Turner model 112; Sequoia-Turner Corporation) was employed to quantify the amount of $\mathrm{Chl} a$ in the supernatant of centrifuged extracts (Wintermans \& De Mots, 1965). Chl $a$ concentration was calculated using the absorption coefficient reported by Wintermans \& De Mots (1965); fluorimetric determinations were calibrated using pure Anacystis $\mathrm{Chl} a$ (Sigma) in $95 \%$ ethanol.

Gas mixtures. Gas mixtures were made using a two-way gas flowmeter/proportioner (Matheson 7300 series) in which $\mathrm{O}_{2}$ and $\mathrm{N}_{2}$ were combined to produce mixtures containing $5,10,20$, and $40 \mathrm{kPa}$ $\mathrm{O}_{2}$. The gas mixtures were introduced by gas displacement of the headspace in the $117.5 \mathrm{ml}$ sealed serum bottles containing $20 \mathrm{ml}$ culture medium. $\mathrm{CO}_{2}$ was then introduced into the culture bottles using a syringe fitted with a 23-gauge hypodermic needle to a constant level of $0.04 \mathrm{kPa}$. Filled bottles were then agitated gently for about $1 \mathrm{~min}$ to equilibrate the gas and liquid phases.

Heterocyst envelope thickness. On day 12 of the experiment, a $1 \mathrm{ml}$ sample from each of two replicate serum bottles per $\mathrm{pO}_{2}$ treatment was viewed under dark-field microscopy using a Nikon Labophot photomicroscope. Photomicrographs of the samples on Kodak Panatomic-x film were enlarged to achieve approximately 2000 -fold magnification of $A$. flos-aquae heterocysts. Heterocyst envelope thickness in the photomicrographs of samples grown at various $\mathrm{pO}_{2}$ values was measured using a calibrated electronic digitizer connected to a microcomputer. Fifteen heterocysts per $\mathrm{pO}_{2}$ treatment were randomly selected for wall thickness measurements.

Because heterocyst envelope thickness of low- $\mathrm{pO}_{2}$ samples reached the limit of resolution of light microscopy (approx. $0.3 \mu \mathrm{m}$ ), we repeated the entire experiment utilizing transmission electron microscopy (TEM) to verify responses observed with light microscopy. In this second experiment, samples collected on day 12 of incubation from each $\mathrm{pO}_{2}$ treatment were fixed with $2 \%(\mathrm{v} / \mathrm{v})$ glutaraldehyde, transferred to BEEM capsule chambers (Day, 1974), postfixed for $1 \mathrm{~h}$ in aqueous $1 \%(\mathrm{w} / \mathrm{w}) \mathrm{OsO}_{4}$ and dehydrated using an ethanol series. This method of fixation does not stain the laminated glycolipid layer of the heterocyst (Fay \& Lang, 1971). Hence, we refer to the region occupied by the laminated glycolipid layer as the glycolipid layer area. Our fixation procedure may also cause shrinkage in the various layers of the heterocyst envelope. Although we were unable to evaluate the degree of shrinkage, it should be the same for all samples processed, so that evaluation of relative changes in layer or layer area thickness should be valid. The dehydrated filaments were then embedded (with care given to orientation of filaments) and thin-sectioned (Brawner \& Cutler,
1987). A Zeiss model EM 10C/CR electron microscope was used to photograph and measure directly the thickness of the glycolipid layer area of the heterocyst envelope (using a digitizing attachment on the microscope) of 30 randomly selected heterocysts from each $\mathrm{pO}_{2}$ treatment. Measurements were made at magnifications ranging from 8000 to 10000 . Three or four measurements were made on the lateral portions of each heterocyst envelope, avoiding polar regions where wall thickness varied considerably. The entire envelope was measured on the dark-field photomicrographs; only the glycolipid layer area of the envelope was repeatedly measured on the TEM preparations.

Nitrogenase activity. Nitrogenase activity of two replicate samples from each experimental $\mathrm{pO}_{2}$ level was assayed, without altering $\mathrm{pO}_{2}, 6$ and $12 \mathrm{~d}$ (late exponential and stationary phase, respectively) after the beginning of the experiment using the acetylene reduction assay (Stewart et al., 1967). Acetylene was added at $10 \%$ of the bottle volume; incubation was for $3 \mathrm{~h}$ under the same experimental conditions. Ethylene produced was determined by flame-ionization gas chromatography (Carle AGC series 100) based on ethylene standards. Separate experiments in our laboratory have shown that nitrogenase activity in $A$. flos-aquae, at the rates observed, is essentially linear for at least $6 \mathrm{~h}$. The rate of ethylene production for each sample was normalized to $\mathrm{Ch}$ l $a$. Nitrogenase activity was also determined initially and at 24 and $48 \mathrm{~h}$ intervals following transfer to $20 \mathrm{kPa} \mathrm{pO}_{2}$ of samples grown for $12 \mathrm{~d}$ at 10,20 and $40 \mathrm{kPa} \mathrm{pO}_{2}$.

Heterocyst frequency. On days 6 and 12 of the experiment, heterocyst frequency (mean number of heterocysts expressed as a percentage of total number of heterocysts plus vegetative cells counted per trichome) of four subsamples from each of two replicate incubation bottles per $\mathrm{pO}_{2}$ treatment was determined by light microscopy. All heterocysts and vegetative cells from individual trichomes were included in the counting procedure. This protocol resulted in approximately 300 vegetative cell counts per subsample per $\mathrm{pO}_{2}$ treatment. Vegetative cell lengths (longitudinal) were obtained from enlarged photomicrographs on 20 random cells (from different trichomes) from each replicate vial of each $\mathrm{pO}_{2}$ treatment.

Growth rate. Growth rates of $A$. flos-aquae at various $\mathrm{pO}_{2}$ values were determined by changes in $\mathrm{Chl} a$ in a $2 \mathrm{ml}$ sample removed just before starting the experiment and on days 6 and 12 of incubation. The change in Chl $a$ concentration was divided by the integral average $\mathrm{Chl} a$ level (assuming exponential growth) between each time interval to yield $\mathrm{Chl}$ $a$ specific growth.

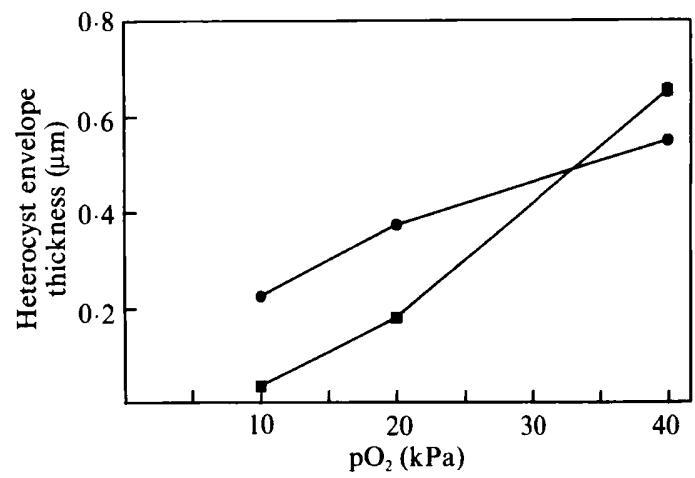

Fig. 1. Heterocyst envelope thickness of $A$. flos-aquae on day 12 of incubation at various $\mathrm{pO}_{2}$ levels. Measurements were obtained from digitized (dark-field) photomicrographs $(n=15)(\bullet)$ and digitized on-line TEM fields $(n=30)(\square)$. Error bars, denoting standard error, were all smaller than the symbols. TEM measurements represent the thickness of the glycolipid layer area only. See text for details. 

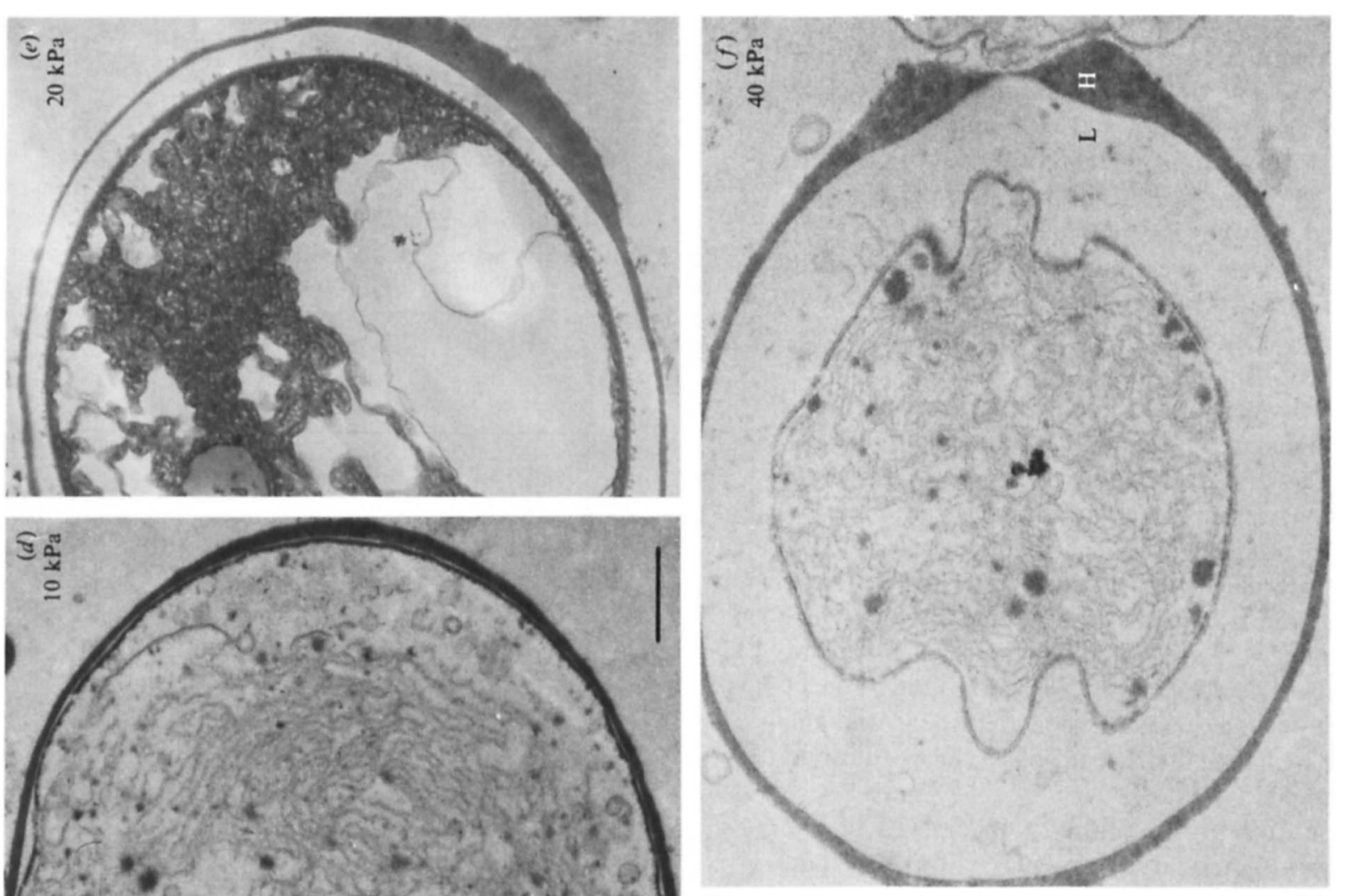

范总客

政

응

要

언

㻤告

营

跣

递

Ji

定照

क

올 $\stackrel{\infty}{=}$

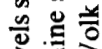

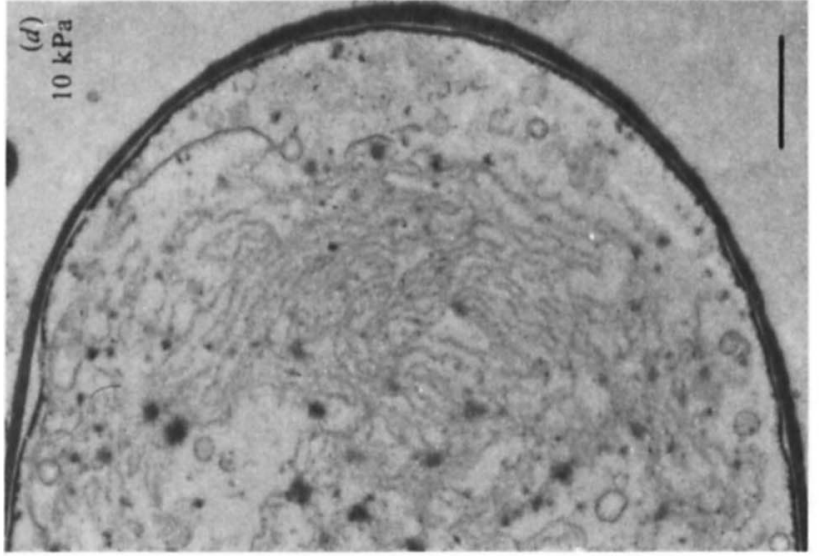

造

定产

号焉

要

两

跣

政

ฐँ

ডั

政

응

원을

出还

.
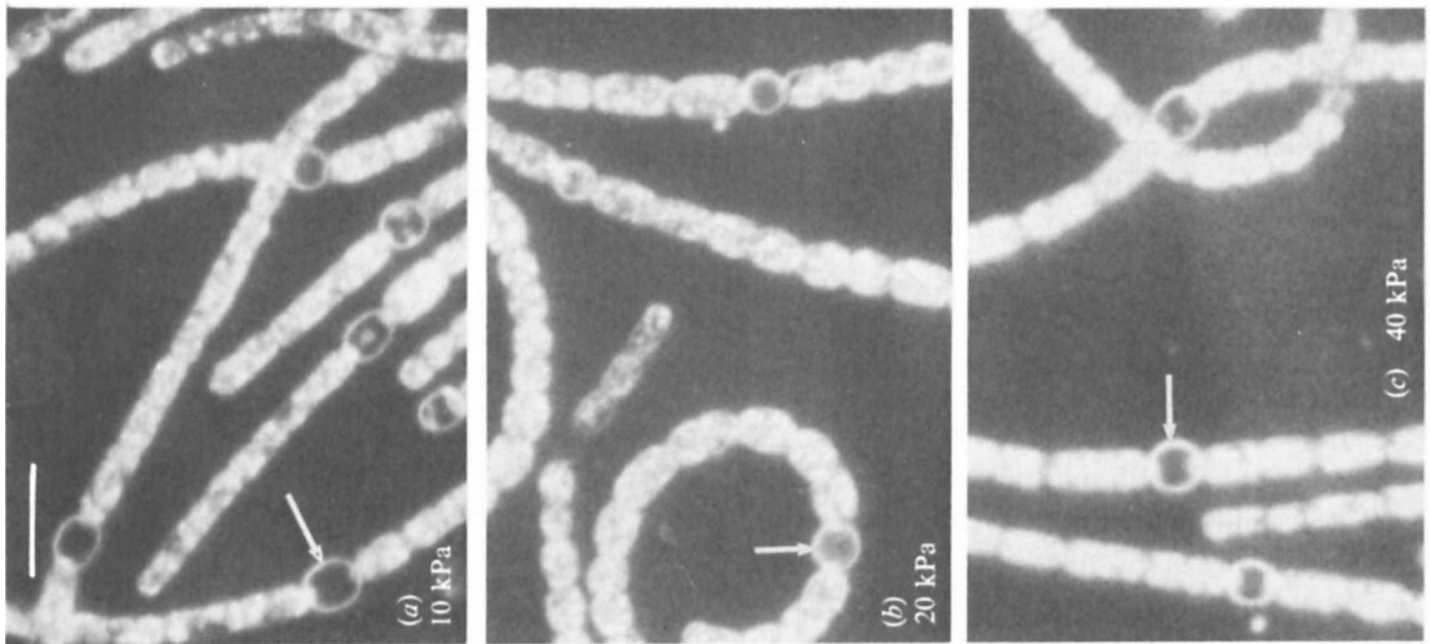

등 홍

옴

층 동

㣢

政

है के

蛋

동

政

형

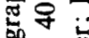

응 동

हี

월

क.

定音商 


\section{Results}

Heterocyst envelope thickness of $A$. flos-aquae, measured by light microscopy and TEM (glycolipid layer area only), following $12 \mathrm{~d}$ of incubation at various $\mathrm{pO}_{2}$ is shown in Fig. 1; samples grown at $5 \mathrm{kPa}$ were not included in TEM analysis. Selected photo- and electron micrographs of whole and thin-sectioned $A$. flos-aquae heterocysts in cultures grown at 10,20 and $40 \mathrm{kPa} \mathrm{pO}$ are shown in Fig. 2. Light microscopy and TEM both revealed that the thickest heterocyst envelopes consistently occurred at $40 \mathrm{kPa} \mathrm{pO}_{2}$. Envelope thickness decreased as $\mathrm{pO}_{2}$ was lowered to $10 \mathrm{kPa}$. TEM revealed that the glycolipid layer area of the envelope responded to changes in $\mathrm{pO}_{2}$ more than the polysaccharide layer. The difference in thickness of the polysaccharide layer between cells grown at $10 \mathrm{kPa}$ and $40 \mathrm{kPa} \mathrm{pO}_{2}$ was about 2.5-fold, whereas a 16-fold difference in thickness occurred in the glycolipid layer area. No significant difference in heterocyst envelope thickness among $\mathrm{pO}_{2}$ levels was observed on day 6 of incubation (data not shown). The internal structure of the heterocysts within and between each treatment showed considerable variation. Currently we have no data which could explain this variability. The electron micrographs shown reflect typical envelope thickness for each treatment and the typical range of internal structure observed within and among treatments.

Nitrogenase activity on both day 6 and 12 of the incubation was highest at $20 \mathrm{kPa} \mathrm{pO}_{2}$ (Fig. 3). When cultures grown at $10 \mathrm{kPa}, 20 \mathrm{kPa}$ and $40 \mathrm{kPa} \mathrm{pO}$ were transferred to $20 \mathrm{kPa} \mathrm{pO}_{2}$, the $40 \mathrm{kPa} \mathrm{pO}_{2}$ culture had the highest nitrogenase activity following $24 \mathrm{~h}$ of incubation (Table 1).

Heterocyst frequency of $A$. flos-aquae on day 6 of the incubation was highest at $5 \mathrm{kPa}$ and lowest at $20 \mathrm{kPa}$ $\mathrm{pO}_{2}$. On day $12,40 \mathrm{kPa} \mathrm{pO}_{2}$ produced the highest heterocyst frequency, although it was not statistically different from that at $5 \mathrm{kPa}$; the lowest heterocyst frequency again occurred at $20 \mathrm{kPa} \mathrm{pO}_{2}$ (Fig. 4). A high proportion of elongated vegetative cells showing no indications of septation occurred at 5 and $40 \mathrm{kPa} \mathrm{pO}$. Measurements of 20 random cells on day 12 revealed that mean vegetative cell lengths ( $\mu \mathrm{m} \pm$ standard error) were $7.80 \pm 0.36$ at $5 \mathrm{kPa}, 6.25 \pm 0.29$ at $10 \mathrm{kPa}, 5.81 \pm 0.23$ at $20 \mathrm{kPa}$, and $7 \cdot 19 \pm 0.25$ at $40 \mathrm{kPa} \mathrm{pO}_{2}$. Elongated cells were rarely found at $20 \mathrm{kPa}$. Chlorophyll $a$ specific growth ( $\mathrm{d}^{-1}$; mean \pm standard error) of $A$. flos-aquae at $5,10,20$ and $40 \mathrm{kPa} \mathrm{O}$ was $0.068 \pm 0.000,0.347 \pm 0.000$, $0.380 \pm 0.003$ and $0.218 \pm 0.014$ during the first $6 \mathrm{~d}$ of incubation, and $0.024 \pm 0.024,0.025 \pm 0.005$, $0.016 \pm 0.006$ and $0.014 \pm 0.014$ between days 6 and 12 of incubation, respectively. These growth data showed that

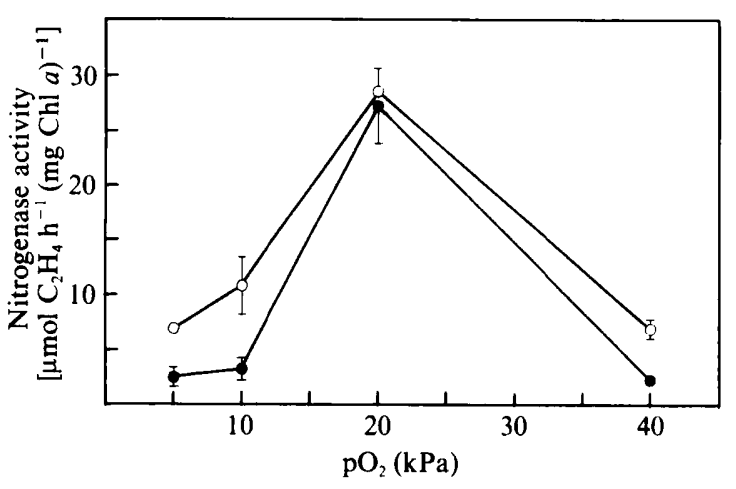

Fig. 3. Nitrogenase activity of A. flos-aquae grown at various $\mathrm{pO}_{2}$ levels, on days $6(O)$ and $12(\bullet)$ of incubation. Error bars denote standard error. When not present, error bars were smaller than the symbols. $n=2$.

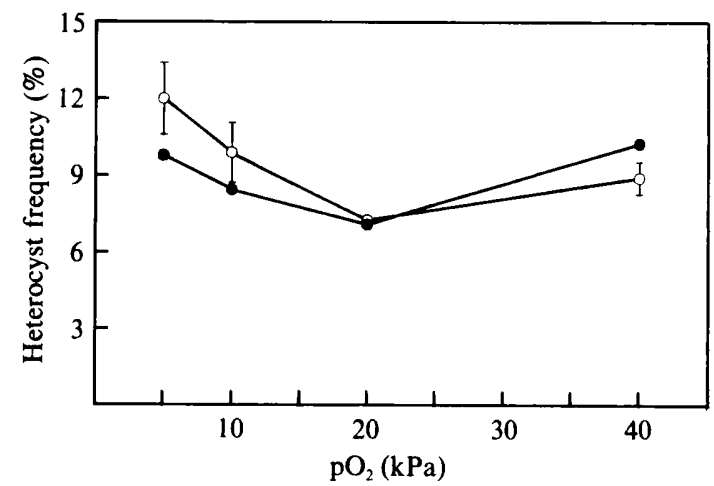

Fig. 4. Heterocyst frequency of $A$. flos-aquae grown at various $\mathrm{pO}_{2}$ levels, on days $6(O)$ and $12(\bullet)$ of incubation. Error bars denote standard error. When error bars are not shown they were smaller than the symbols. $n=8$.

Table 1. Nitrogenase activity of $A$. flos-aquae transferred to $20 \mathrm{kPa} \mathrm{pO}_{2}$ from 10,20 or $40 \mathrm{kPa} \mathrm{pO} \mathrm{P}_{2}$ after $12 \mathrm{~d}$ growth

\begin{tabular}{cccc}
\hline \hline & \multicolumn{3}{c}{ Nitrogenase activity* } \\
\cline { 2 - 4 } $\begin{array}{c}\text { Initial } \\
\text { growth } \\
\text { condition } \\
(\mathrm{pO}, \mathrm{kPa})\end{array}$ & $\begin{array}{c}\text { Before } \\
\text { transfer }\end{array}$ & \multicolumn{2}{c}{ After transfer } \\
\cline { 2 - 4 } & \multicolumn{2}{c}{$\mathrm{h}$} & $48 \mathrm{~h}$ \\
\hline 10 & $4.28 \pm 0.48$ & $3.20 \pm 0.60$ & $2.45 \pm 0.45$ \\
20 & $24.60 \pm 2.10$ & $19.40 \pm 0.80$ & $20.90 \pm 0.30$ \\
40 & $4.41 \pm 0.38$ & $20.90 \pm 0.40$ & $22.85 \pm 0.75$ \\
\hline \hline
\end{tabular}

- Mean ( \pm standard error; $n=2$ ) nitrogenase activity, $\mu \mathrm{mol}$ $\mathrm{C}_{2} \mathrm{H}_{4} \mathrm{~h}^{-1}(\mathrm{mg} \mathrm{Chl} a)^{-1}$, before transfer, and at 24 and $48 \mathrm{~h}$ after transfer to $20 \mathrm{kPa} \mathrm{pO}_{2}$.

the highest rates generally occurred between 10 and $20 \mathrm{kPa} \mathrm{O}_{2}$. The high errors associated with the specific growth rates at 5 and $40 \mathrm{kPaO}_{2}$ between days 6 and 12 of incubation make these particular rates suspect. 


\section{Discussion}

Heterocyst envelope layers provide a passive barrier to $\mathrm{O}_{2}$ diffusion (Murry et al., 1984; Murry \& Wolk, 1989; Stanier \& Cohen-Bazire, 1977). Our results indicate that both the homogeneous polysaccharide layer and the laminated glycolipid layer area of the heterocyst envelope in the cyanobacterium $A$. flos-aquae increased in thickness in response to prolonged exposure (12 d) to high exogenous $\mathrm{pO}_{2}$, an observation similar to that noted in Frankia vesicle wall morphogenesis (Parsons et al., 1987). Conditions of prolonged $\mathrm{O}_{2}$ supersaturation have been measured in the surface waters during late spring in Hebgen Lake, the site from which $A$. flos-aquae was isolated (J. C. Priscu, unpublished data). Hence, the ability to regulate envelope thickness may enhance the fitness of this organism, and possibly other heterocystous cyanobacteria, in nature.

The culture grown at $40 \mathrm{kPa} \mathrm{pO}_{2}$ showed a considerable increase in nitrogenase activity following transfer to $20 \mathrm{kPa} \mathrm{pO}$, while the two cultures grown at 10 and $20 \mathrm{kPa} \mathrm{pO}_{2}$ showed no increase following transfer. These results imply an inducible nature of heterocyst envelope thickness in response to $\mathrm{pO}_{2}$ which can protect nitrogenase by mediating inward $\mathrm{O}_{2}$ diffusion. Our observation is in agreement with previous reports of poor development of heterocyst walls in Anabaena species under anaerobic or microaerobic conditions (Kulasooriya et al., 1972; Rippka \& Stanier, 1978). Heterocyst envelope components, such as the laminated glycolipid layer and the homogeneous polysaccharide layer, have been shown to be important as gas diffusion barriers (Murry \& Wolk, 1989). According to Walsby (1985) the maximum rate of oxygen diffusion into a heterocyst is nearly half that of nitrogen when the inside concentration of these gases is zero. This is because the molar concentration of oxygen dissolved in water equilibrated with air $(258 \mu \mathrm{M})$ is nearly half the equilibrium concentration of nitrogen $(506 \mu \mathrm{M})$. These diffusion rates will change rapidly when the environmental oxygen/nitrogen ratio is changed. The permeability of the heterocyst envelope to oxygen/ nitrogen depends on the number of layers of glycolipid in the heterocyst envelope (Walsby, 1985). Producing a thick heterocyst envelope (either the glycolipid layer or the polysaccharide layer) could be a metabolically 'expensive' process so that organisms presumably form thicker envelopes only when necessary.

That optimum nitrogenase activity of $A$. flos-aquae occurred at $20 \mathrm{kPa} \mathrm{pO}_{2}$ under prolonged growth indicates that nitrogenase activity was regulated by other factors as well as external $\mathrm{pO}_{2}$. Prolonged growth at $40 \mathrm{kPa} \mathrm{pO}_{2}$ apparently induced physiological stress leading to reduced nitrogenase activity. Optimum nitro- genase activity should have occurred at 5 or $10 \mathrm{kPa} \mathrm{pO}$ instead of $20 \mathrm{kPa}$ if regulated directly by exogenous $\mathrm{pO}_{2}$. Our data imply that $20 \mathrm{kPa} \mathrm{pO}_{2}$ provides a general physiological optimum. The observation that the culture transferred to $20 \mathrm{kPa}$ from $40 \mathrm{kPa} \mathrm{pO}_{2}$ showed higher nitrogenase activity, compared to those transferred from 10 and $20 \mathrm{kPa} \mathrm{pO}_{2}$, indicates that thicker heterocyst envelopes offer better protection of nitrogenase from $\mathrm{O}_{2}$-inactivation. This observation also implies a degree of recovery from physiological stress at $40 \mathrm{kPa} \mathrm{pO}_{2}$. Kulasooriya et al. (1972) showed that short-term anaerobic growth of $A$. cylindrica with highly elevated $\mathrm{CO}_{2}$ levels increased nitrogenase activity, followed by a rapid decline. Azide, an inhibitor of cytochrome activity, strongly suppressed nitrogenase activity in $A$. cylindrica under aerobic conditions, indicating a reliance of nitrogenase activity on active respiration (Murry et al., 1984). This contention assumes that azide does not inhibit nitrogenase directly. Presumably, the negative effect of energy limitation in $A$. flos-aquae at low $\mathrm{pO}_{2}(5$ and $10 \mathrm{kPa}$ ) counters the positive influence of reduced $\mathrm{O}_{2}$ inhibition of nitrogenase at 5 and $10 \mathrm{kPa} \mathrm{pO}_{2}$. High $\mathrm{pO}_{2}$, apart from its direct inhibitory effect on nitrogenase, could also inhibit the fixation of inorganic $\mathrm{C}$ by photosynthesis through photooxidation and photorespiration, which are energy-consuming processes (Van Liere \& Walsby, 1982).

Our data indicate that prolonged exposure to elevated oxygen tension or microaerobiosis is detrimental to A. flos-aquae because the fundamentally important processes of $\mathrm{CO}_{2}$ and $\mathrm{N}_{2}$ fixation can be affected. We conclude that $A$. flos-aquae achieves optimal growth at ambient atmospheric $\mathrm{pO}_{2}$ (near $20 \mathrm{kPa}$ ) despite its ability to produce a thicker heterocyst envelope at elevated $\mathrm{pO}_{2}$. The tradeoff between morphogenic and physiological adaptations to varying $\mathrm{pO}_{2}$ conditions in all likelihood involves a complicated interplay of genetic flexibility, bioenergetics (including the metabolic 'costs' of altering and maintaining cell morphology in response to environmental stress) and biochemical limitations (to $\mathrm{O}_{2}$ stress, $\mathrm{N}$ starvation, and availability of energy and reductant). The ability to regulate heterocyst envelope thickness may have selective advantages for A. flosaquae in $\mathrm{N}$-deficient, $\mathrm{O}_{2}$-rich environments such as those found in the near surface waters of Hebgen Lake (the site of isolation). The biosynthetic processes responsible for altering heterocyst envelope thickness may be of physiological and evolutionary significance when considering long-term increases in oxygenation of the biosphere during the inception and development of oxygenic photosynthesis.

We express our gratitude to T. Galli and L. Priscu for assistance in the laboratory, Susan Zasky for assistance with electron microscopy, 
and M. Lizotte for reviewing the manuscript. The comments of J. Meeks and two anonymous reviewers greatly improved the manuscript. This research was supported by a grant from The Soap and Detergent Association.

\section{References}

ALLEN, M. M. (1968). Simple conditions for growth of unicellular bluegreen algae on plates. Journal of Phycology 4, 1-4.

BRAWNER, D. L. \& CUTLER, J. E. (1987). Cell surface and intracellular expression of two Candida albicans antigens during in vitro and in vivo growth. Microbial Pathogenesis 2, 249-257.

Carlton, R. G. \& Paerl, H. W. (1989). Oxygen-induced changes in morphology of aggregates of Aphanizomenon flos-aquae (Cyanophyceae): implications for nitrogen fixation potentials. Journal of Phycology 25, 326-333.

Carpenter, E. J. \& Price, C. C. (1976). Marine Oscillatoria (Trichodesmium): explanation for aerobic nitrogen-fixation without heterocysts. Science 191, 1278-1280.

DAY, J. W. (1974). A BEEM capsule chamber pipette for handling small specimens for electron microscopy. Stain Technology 49, 408-410.

ElhaI, J. \& Wolk, C. P. (1990). Developmental regulation and spatial pattern of expression of the structural genes for nitrogenase in the cyanobacterium Anabaena. EMBO Journal 9, 3379-3388.

FAY, P. \& CoX, R. M. (1967). Oxygen inhibition of nitrogen fixation in cell-free preparations of blue-green algae. Biochimica et Biophysica Acta 143, 562-569.

FAY, P. \& LANG, N. J. (1971). The heterocysts of blue-green algae. I. Ultrastructural integrity after isolation. Proceedings of the Royal Society B178, 185-192.

FoGG, G. E. (1949). Growth and heterocyst production in Anabaena cylindrica Lemm. II. In relation to carbon and nitrogen metabolism. Annals of Botany 13, 241-259.

Kangatharalingam, N., Dodds, W. K., Priscu, J. C. \& Paerl, H. W. (1991). Nitrogenase activity, photosynthesis, and the degree of heterocyst-aggregation in the cyanobacterium Anabaena flos-aquae. Journal of Phycology 27, 680-686.

Kulasooriya, S. A., LaNG, N. J. \& Fay, P. (1972). The heterocysts of blue-green algae. III. Differentiation and nitrogenase activity. Proceedings of the Royal Society B181, 199-209.
Murry, M. A. \& WolK, C. P. (1989). Evidence that the barrier to the penetration of oxygen into heterocysts depends upon two layers of the cell envelope. Archives of Microbiology 151, 469-474.

Murry, M. A., Horne, A. J. \& Benemann, J. R. (1984). Physiological studies of oxygen protection mechanisms in the heterocysts of Anabaena cylindrica. Applied and Environmental Microbiology 47, 449-454.

Paerl, H. W (1978). Light-mediated recovery of $\mathrm{N}_{2}$-fixation in the blue-green algae Anabaena spp. in $\mathrm{O}_{2}$ supersaturated waters. Oecologia 32, 135-139.

Parsons, R., Silvester, W. B., Harris, S., Gruitters, W. T. M. \& Bullivant, S. (1987). Frankia vesicles provide inducible and absolute oxygen protection for nitrogenase. Plant Physiology 83, 728-731.

RippKa, R. \& Stanier, R. Y. (1978). The effects of anaerobiosis on nitrogenase synthesis and heterocyst development by Nostocacean cyanobacteria. Journal of General Microbiology 105, 83-94.

Robson, R. L. \& Postgate, J. R. (1980). Oxygen and hydrogen in biological nitrogen fixation. Annual Review of Microbiology 34, 183-207.

SARTORY, D. P. \& GrobbelaAR, J. U. (1984). Extraction of chlorophyll $a$ from fresh water phytoplankton for spectrometric analysis. Hydrobiologia 114, 177-187.

Smith, R. J., Hobson, S. \& Ellis, I. R. (1987). The effect of abscisic acid on calcium-mediated regulation of heterocyst frequency and nitrogenase activity in Nostoc 6720. New Phytology 105, 543-549.

StaNier, R. Y.\& CohEn-Bazire, G. (1977). Phototrophic prokaryotes: the cyanobacteria. Annual Review of Microbiology 31, 225-274.

Stewart, W. D. P., Fitzgerald, G. P. \& BurRIS, R. H. (1967). In situ studies on $\mathrm{N}_{2}$ fixation using the acetylene reduction technique. Proceedings of the National Academy of Sciences of the United States of America 58, 2071-2078.

VAN LIERE, L. \& WALSBY, A. E. (1982). Interactions of cyanobacteria with light. In The Biology of Cyanobacteria, 2nd edn, pp. 9-45. Edited by N. G. Carr \& B. A. Whitton. Oxford: Blackwell Scientific Publications.

WaLSBY, A. E. (1985). The permeability of heterocysts to the gases nitrogen and oxygen. Proceedings of the Royal Society B226, 345-366.

Wintermans, J. F. G. M. \& De Mots, A. (1965). Spectrophotometric characteristics of chlorophylls $a$ and $b$ and their pheophytins in ethanol. Biochimica et Biophysica Acta 109, 448-453.

Wolk, C. P. (1982). Heterocysts. In The Biology of Cyanobacteria, 2nd edn, pp. 359-386. Edited by N. G. Carr \& B. A. Whitton. Oxford: Blackwell Scientific Publications. 